\title{
FLOOD MANAGEMENT STRATEGIES IN FREQUENT AND SMALL SCALE EVENTS: LESSONS LEARNED FROM AMARANTE (PORTUGAL)
}

\author{
Fantina Tedim, Salete Carvalho \\ University of Porto, Faculty of Arts, Porto, Portugal
}

Manuscript received: June 10, 2010

Revised version: August 1, 2010

Tedim F. \& Carvalho S., 2010. Flood management strategies in frequent and small scale events: lessons learned from Amarante (Portugal). Quaestiones Geographicae 29(3), Poznań 2010, pp. 69-84, 10 Figs, 6 Tabs. ISBN 978-8362662-04-3. ISSN 0137-477X. DOI: 10.2478/v10117-010-0024-3.

ABSTRACT. The 2000/2001 winter was exceptionally rainy in Portugal and between November 2000 and March 2001 several floods occurred. In this period some localities registered the highest floods of the last hundred years. One example is the town of Amarante, in the north of Portugal, that has been affected by several flood events during the time frame previously mentioned. There is no reference of these episodes in the international disaster databases (e.g. Em-dat, Darmouth Flood Observatory) because it is a very small scale event, and no fatalities were recorded. However, it is a recurrent situation with considerable direct and indirect damages which affects a small part of the cultural heritage centre which is also an important touristic and commercial area.

The objective of this paper is to understand the characteristics of flood risk in Amarante which is a product of the hazard and the vulnerability of exposed elements (e.g. people, environment and structures) in order to improve flood disaster management efficiency.

The paper is organized into two parts. On the first one we add new data to the previous knowledge through the identification of flood episodes in two time periods, between 1937 and 1955 and from 1985 to 2001. Each event was characterized according to several parameters (e.g. flood peak, water height, flooding area, duration, and flow velocity) and classified into six levels according to flood magnitude (water height), flooded area (extension) and potential impacts (damages). This approach improves hazard knowledge and systematizes emergency response procedures. It can improve the communication, not only between the different civil protection agents, but also between them and the citizens during the emergency. It can also be useful for assurance companies' policy.

The second part is focused on the management of the $21^{\text {st }}$ of March 2001 flood which was the most severe in Amarante's history at least in the last hundred years. Understanding the damages and the impacts of flood on livelihoods, the emergency procedures, as well as the articulation between people and civil protection agents are fundamental to increase the efficiency of flood risk management strategies and the determination of appropriate protection levels.

KEYWORDs: flood, risk management, small scale, urban area, disaster response, Portugal

Fantina Tedim, Salete Carvalho, University of Porto, Faculty of Arts, Via Panorâmica, 4150-564 Porto,Portugal, e-mail: ftedim@letras.up.pt, scarvalho@letras.up.pt 


\section{Introduction}

Amarante is a small town on the north of Portugal, frequently affected by floods. There is no mention of these events in the international disaster databases (e.g. Em-Dat, Darmouth Flood Observatory) as they are small scale events and no fatalities have ever been registered. The flooded area is never very large due to the topography of the valley, but affects part of the cultural heritage centre as well as a very important commercial area. This is considered as flood risk prone area in the Portuguese national scale in the Douro River Catchment Plan (INAG 2001) and in the National Water Plan (INAG 2001, 2002).

In fact, disasters differ in scale between very large and somewhat smaller (OFDA 1999). However, independently of descriptors, size is a relative value and if Amarante floods have no expression at the international level, they have important impacts at the local scale. Even though no fatalities have ever been reported, losses are significant. Moreover, each time a flood occurs an emergency response is implemented which has inherent costs. Knowledge about flood risk and emergency management procedures can increase the level of protection of people and goods and decrease the losses. Even for small scale events there is the need to coordinate efforts and efficient and effective countermeasure selection based on the evaluation of pre- and post-event strategies (Hansson et al. 2008) is necessary.

The town of Amarante is situated on both banks of the Tâmega River and is located in one of the flood risk-prone areas of this drainage ba$\sin$. Tâmega is an international river that can be considered as a middle-size catchment with a length of $184.02 \mathrm{~km}$ and a drainage basin about $3,309 \mathrm{~km}^{2}$ most of it $\left(80 \% ; 2,649 \mathrm{~km}^{2}\right)$ inside Portuguese boundaries (Fig. 1). The annual average discharge is $70.31 \mathrm{~m}^{3} / \mathrm{s}^{-1}$ and the average slope of the basin is $17.44 \%$ (INAG 2010). It is one of the tributaries of the right bank of Douro River. The catchment area in Portuguese territory has a population density of 92.7 inhabitants $/ \mathrm{km}^{2}$, being, nevertheless, dominated by forest $(61 \%)$ and

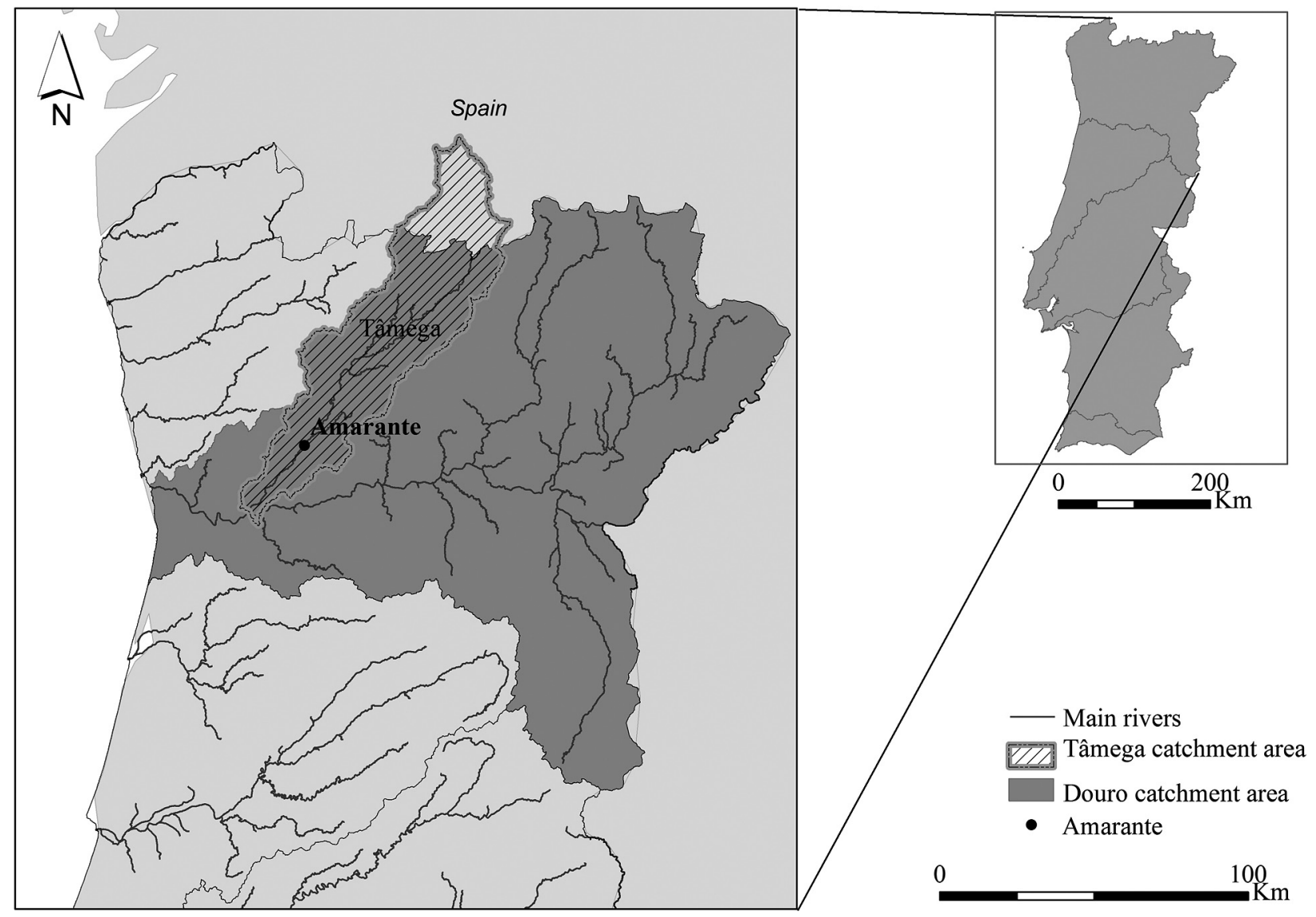

Fig. 1. Localization of Tâmega catchment on the north of Portugal. 
agricultural lands (38\%). The urban area represents only $1.5 \%$ of the surface. Until now there are no dams upstream Amarante but this situation will change in the near future. Since 1988 there is a dam downstream of the town, which impact ends just in Amarante.

The application to flood of different models of risk assessment have been proposed by several authors (e.g. Kron 2002; Jonkman et al. 2008; Merz \& Thieken 2009; Kreibich et al. 2009; Moël et al. 2009). However, all agree that risk is a combination of hazard characteristics and its probability of occurrence, with potential consequences on the human and environmental systems. Kreibich et al. (2009) consider that flood risk encompasses two aspects: 1) flood hazard characterised by parameters such as probability and water depth; 2) vulnerability often due to exposure and susceptibility of affected elements. Moël et al. (2009) introduced a new element as they consider that not only the exposure but also coping capacity makes up potential consequences. Nonetheless, the authors recognize that if exposure is easy to evaluate even if certain kind of indirect damages are still difficult to quantify, the definition of coping capacity indicators are not easy to integrate in risk assessment (Moël et al. 2009). The risk assessment framework we proposed in this paper identifies two main components: hazard evaluation and vulnerability assessment composed by exposure, susceptibility and coping capacity.

Although, the awareness of frequency of the flood hazard in Amarante is scarce the knowledge of flood parameters is even more limited (e.g. duration, flood peak, flooding area, water height and flow velocity). However, it is a key task in flood hazard assessment. Actually, the availability of reliable and spatially distributed event parameters for extreme floods is a fundamental prerequisite for any comprehensive approach (Büchele et al. 2006). The implementation of the EU Directive 2007/60 on the management of flood risk requires information on flood hazard as well as on flood damages.

Historical floods should serve as realistic reference scenarios for exceptional events. The consideration of extreme historical events can not only support flood awareness as realised sce- narios (under historical conditions), but also be used as reference for the analysis of potential extreme cases under present conditions (Büchele et al. 2006).

The 2000/2001 winter was exceptionally rainy in Portugal and as usual Amarante was affected by floods. On $21^{\text {st }}$ of March 2001, the largest flood from the last hundred years, at least, was registered. This was the last event of a sequence of seven floods of different magnitudes and duration. In spite of Amarante history of floods, the vulnerability assessment done for the town is still poor.

This paper identifies and tries to answer two orders of questions. The first one related with the flood hazard: when does a flood in Amarante begin? How often is the town affected by floods? How many floods effectively happened during the 2000/2001 winter? The second question concerns the impacts of these events and the emergency response: What were the damages of the $21^{\text {st }}$ of March flood? Is it possible to decrease flood impacts? How can floods be mitigated in this consolidate urban space?

Answer to all these questions in order to improve flood risk management in Amarante and to support emergency planning and an efficient response is the main goal of the present research.

This paper is organized into two parts. The first one focuses on the identification and characterization of flood episodes between 1937 and 2001 which could be very useful to create a database. Each event has been characterized according to several parameters (e.g. flood peak, water height, flooding area, duration, and flow velocity).

The second part of this paper has insight on the $21^{\text {st }}$ of March 2001 flood to systematize the damages associated in order to show the importance of having an evaluation of the losses. Understanding the damages and the impacts of flood on livelihoods, the emergency procedures adopted, as well as the articulation between people and civil protection agents are fundamental to improve the efficiency of flood management strategies and the determination of appropriate protection levels, in order to reduce vulnerability and costs. 


\section{Data and methods}

Until now no floods database had been established for Amarante and the information is very limited for flood events characteristics as well as their consequences. The biggest events (2001, 1939, 1909, and 1962, respectively) are recorded on the walls of some buildings where the height of the water had been registered. Although these are the larger events, other floods have affected this urban area during the $20^{\text {th }}$ century.

The starting point to systematize the historic floods in Amarante was the data found in some qualitative research works (Costa 2002; Gomes \& Costa 2004; Pedrosa \& Costa 1999). These studies used information from newspapers and firefighters reports. The reference period was 1960 to 2001. In order to validate this information several procedures were adopted: research local and national newspapers to confirm and/or complete the information and hydrological data research. The fire-fighters reports were irreversibly damaged and impossible to consult. The local and regional newspapers were useful to identify flood occurrences as well as some elements related with date of occurrence, description of the flooding area and the local impacts. However, the descriptions are merely informative, without a scientific purpose and presented two order of gaps:

1) flood data occurrence is sometimes identified by general sentences as "during last week", "just before Christmas" or "two following days", making it impossible to identify the date of the flood peak. For example the newspaper Flor do Tâmega has a reference to the flood of $21^{\text {st }}$ and $22^{\text {nd }}$ of March as the highest of the century but the peak was on the $21^{\text {st }}$ and the flood duration was longer than two days;

2) some of the descriptions are not precise, comprehensibly considering the purpose of the news, but making it difficult to extract data concerning water level and the flooding area.

Some studies used an indirect quantitative approach (Pedrosa \& Costa 1999), through the use of the maximum daily discharge from hydrological stations upstream and downstream of Amarante, to characterise the flood events previously identified through the press with the inherent limitations.
The hydrological information from a station located on Amarante has not yet been used for research purposes. It is only available for two periods. S. Gonçalo staff gage, which was active between 1937-10-01 and 1955-01-13, provided the height of the water obtained through direct observation. One record of the height of the water per day was established and during the period of activity some changes in the daily hour of observation had to be reported. Only in a situation of possible flood, more values per day were registered which was very useful to understand the flood pattern. This information was provided by the National Water Institute (INAG).

Data between 1985 and 2001 were obtained from a limnimetric station belonging to EDP- Energias de Portugal [EDP-Energies of Portugal] that is a private company. Its location is close to the previous staff gage. The data are registered continuously as a chart and a measurement of the water height is recorded hourly. Due to internal regulations, related to company policies, we did not have access to the data for the whole period (1985-2001), but only for the already identified flood events. The consecutive floods during the 2000/2001 winter affected the equipment and it was not possible to get continuous hydrological data after $26^{\text {th }}$ of January 2001, although some sporadic data were available.

The data for the two mentioned periods, were the support to the definition of flood levels and parameters. We used a topographic site survey to define the altitude of the different exposed elements as well as the water level during the flood.

For the period between 1956 and 1984 the only available data were those referring to daily average discharge for one station upstream (i.e. Ponte Cavez, with data since 1957-11-03) and another downstream of the town (i.e. Ponte de Canavezes with records from 1955-10-01 to 1987-09-30). These data could be used to complement the qualitative information obtained from the newspapers and fire-fighters reports. However, this information was not useful to characterize each event or even to identify the flood peak.

The costs related to the damages after 2000/2001 winter floods are not available, and even the ones associated with the emergency response have not been established. An important 
commercial area is part of the flooding area which led the Associação Comercial de Amarante [Amarante Commercial Association] to make, at the time, a survey to identify the losses of the shop owners and demand of governmental funding.

In order to understand the vulnerability of the area, a survey was implemented during 2009, among citizens who were activ in the flooding area and experienced the 2001 floods. We obtained 18 answers which represent about 30\% of the people affected by the $21^{\text {st }}$ of March flood. At least six shops were closed after the flood but not necessarily because of it. The questionnaire was divided into three parts: characterization of 2000/2001 winter floods, flood management experiences, and flood preparedness. It had single choice, multiple-choice and also rating scales (using five-point Likert Scale) questions. Descriptive statistics were used to analyse collected data. Measures of central tendency, dispersion and cross tabulation were mostly used.

A focus group with people from the municipal emergency service, who participated in the emergency response of 2000/2001 winter floods, and an interview with fire-fighters involved in the response during the same period, were also implemented.

\section{The framework: flood levels}

The EU Directive 2007/60 establishes three flood scenarios (with high, medium and low probability of occurrence) to support risk assessment. Nevertheless, this approach is virtually inadequate to fully describe the whole range of flood events (Tsakiris et al. 2009).

This paper suggests a simple model of classification of floods in six levels according to flood magnitude (water height, flood peak), flooding area and potential impacts (Fig. 2). This approach has a double advantage. On the one hand these levels support diverse scenarios with different probability of occurrence. On the other hand they systematize emergency response procedures according to flood magnitude, improve the communication between the different civil protection agents, as well as between civil protection and

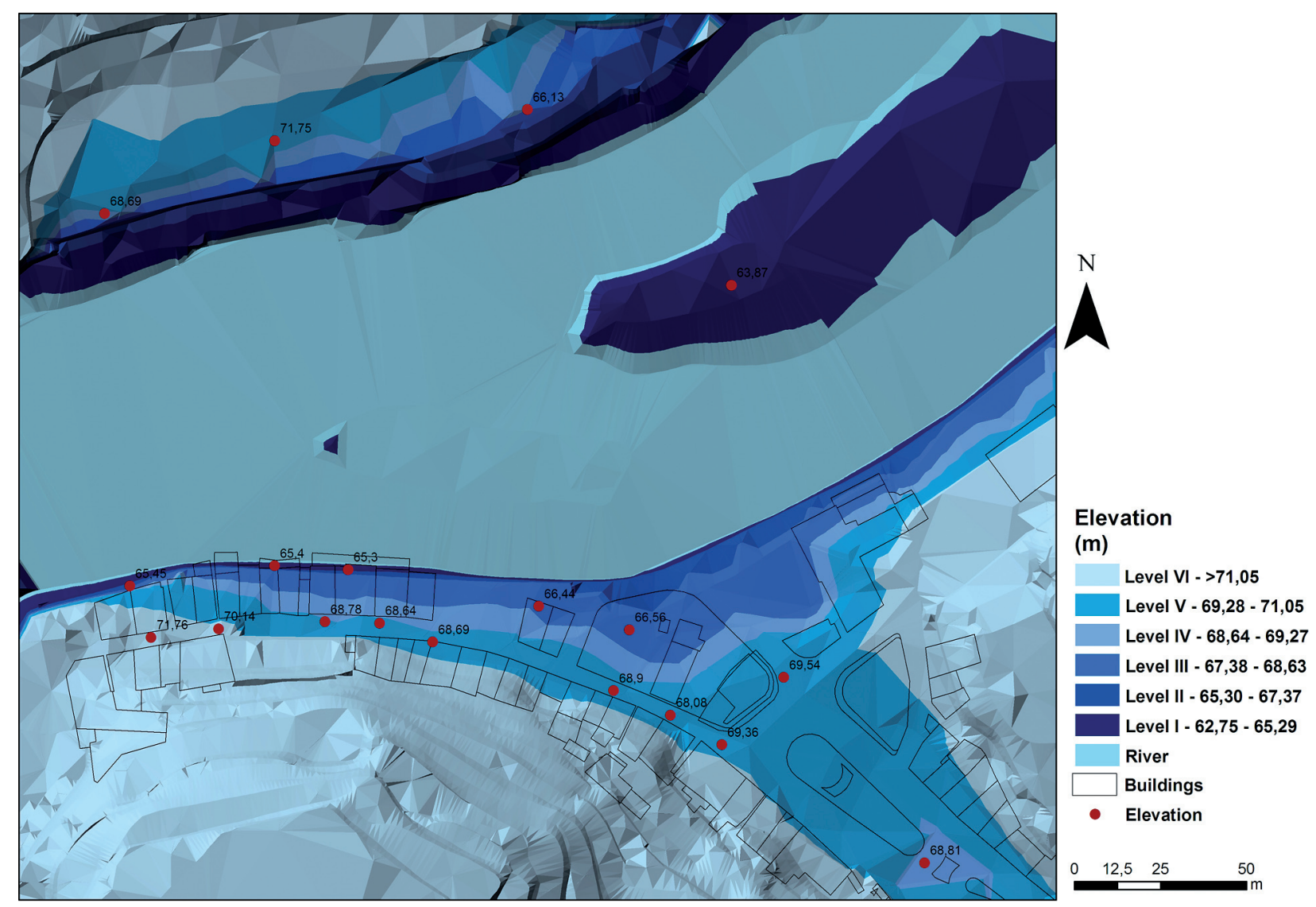

Fig. 2. Inundated area associated with different level of floods. 


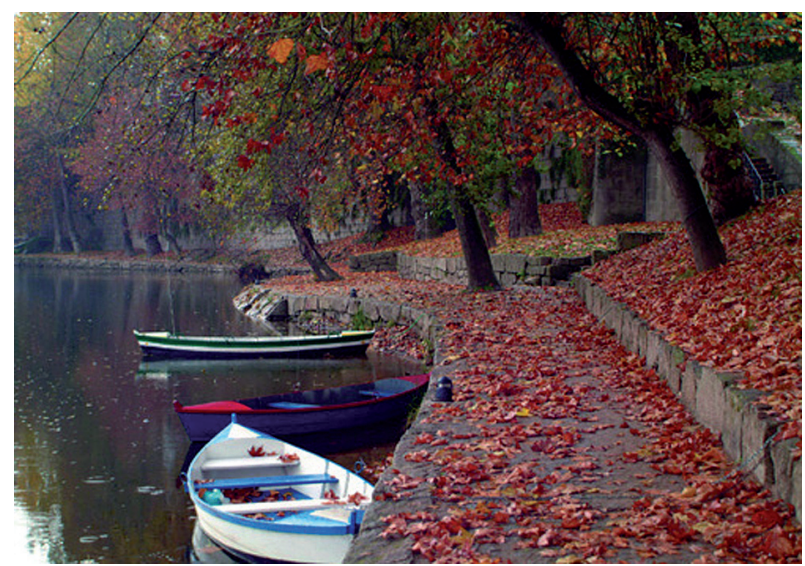

Fig. 3. Tâmega River - Peatonal track on the right river bank. Source: Amarante City Hall (http://www.cm-amarante.pt/).

the citizens during the emergency response. The flood clasification can also be useful for assurance companies' policy.

The observation of the Tâmega valley landscape allowed the definition of the beginning of a flood when the stream overflows the structures on both banks. Three exposed elements were identified: circulation areas (i.e. streets and peatonal tracks), buildings (residential houses, commercial and services equipments) and green areas (gardens, agricultural land and forest areas); each of them supports several economic, social or leisure functions.

In a flood scenario the first structure to be affected would be the peatonal track on the right bank of the river. Its lowest point, with an altitude of $62.75 \mathrm{~m}$ a.s.l., corresponds to the moment that a flood begins (Fig. 3). Nonetheless, the water level must rise $2.55 \mathrm{~m}$ more in order to affect the cellars of the buildings on the left bank of Tâmega River (Fig. 4). For local people a flood begins only when the river starts to affect these cellars. In this situation the losses are not yet necessarily high, however they disturb the daily life of people with stores, restaurants and coffee shops. This disturbance grows with the increase of water level.

Six different levels of floods based on the water height, flooding area, potential damages on exposed elements, were defined for Amarante (Table 1). Each flood level has different likelihood, impact, and implies distinct emergency response. The level VI shows a situation that has never occurred until now. It represents the most extreme potential scenario.

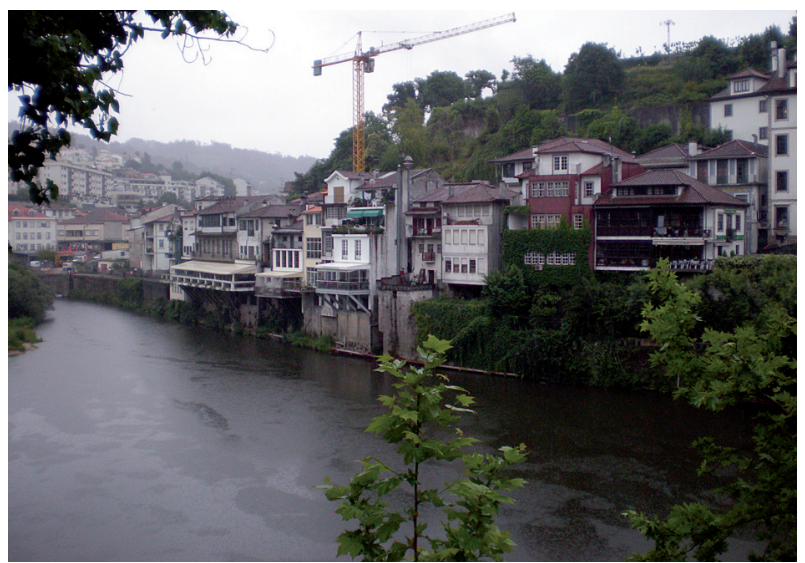

Fig. 4. Floods of level II affect the buildings cellars on the left bank.

This model was defined in function of the Amarante flood risk prone-area. It is a simple and flexible tool that might be adapted to different case studies and it is our purpose to develop and apply it in other territorial contexts in future works (i.e. in other scales, with different kinds of land use) in order to validate it as a tool to support flood risk mitigation and to create a more efficient flood disaster management. Changes in land use affect not only the exposure but can also affect the emergency procedures.

This approach has a double advantage. It integrates flood hazard knowledge with the flooding extension and consequently with the potential impacts. It also defines the procedures related with the emergency response which are related with the magnitude of the event. It can also be useful for land planning and insurance companies as well as to improve the communication between the different civil protection agencies and between civil protection and citizens.

The problem of this approach is the comparability between different places. This fragility can be eliminated by associating it with each of these flood levels a recurrence period.

\section{Flood events}

\section{Flood occurrence between 1937 and 1955}

The first indication for flood hazard can be obtained by looking at how often floods occurred historically and determine their magnitude (Moël et al. 2009). Between October 1937 and January 
Table 1. Characterization of floods level in Amarante

\begin{tabular}{|c|c|c|c|c|}
\hline $\begin{array}{c}\text { Flood } \\
\text { level }\end{array}$ & $\begin{array}{l}\text { Water } \\
\text { height }\end{array}$ & Exposure & Susceptibility & Coping measures \\
\hline I & $\begin{array}{l}\text { Begins } \\
\text { when wa- } \\
\text { ter reaches } \\
62.75 \mathrm{~m} \\
\text { a.s.l. } \\
\text { Ends at } \\
65.29 \mathrm{~m} \\
\text { a.s.l. }\end{array}$ & $\begin{array}{l}\text { Overflow of the fluvial } \\
\text { beach and circulation } \\
\text { structures, on the right } \\
\text { bank of Tâmega River. }\end{array}$ & $\begin{array}{l}\text { Damages: Interruption of the } \\
\text { utilization of exposed structures } \\
\text { which affects leisure. } \\
\text { Potential losses and costs: } \\
\text { Limited - Cleaning of the river } \\
\text { bank; reconstruction of small } \\
\text { damages on support walls. }\end{array}$ & $\begin{array}{l}\text { - Alert of beginning of flood } \\
\text { - Interdiction of people circula- } \\
\text { tion on a part of the right bank of } \\
\text { the river; } \\
\text { - Monitoring river water level; } \\
\text { - Follow the meteorological } \\
\text { forecasts; } \\
\text { - Inform local people of the } \\
\text { forecasts. }\end{array}$ \\
\hline II & $\begin{array}{c}\text { Begins } \\
\text { when wa- } \\
\text { ter reaches } \\
65.30 \mathrm{~m} \\
\text { a.s.l. } \\
\text { Ends at } \\
67.37 \mathrm{~m} \\
\text { a.s.l. }\end{array}$ & $\begin{array}{l}\text { Water begins to affect the } \\
\text { cellars of the buildings } \\
\text { on left bank. } \\
\text { On the right bank the } \\
\text { access to the walkway is } \\
\text { completely blocked. }\end{array}$ & $\begin{array}{l}\text { Damages: Some cellars are inun- } \\
\text { dated, some products could be } \\
\text { destroyed. } \\
\text { Potential losses and costs: } \\
\text { Limited - Mitigation of losses } \\
\text { through convenient information } \\
\text { is possible and still limited. } \\
\text { Cleaning procedures. }\end{array}$ & $\begin{array}{l}\text { - Active surveillance made by } \\
\text { the civil protection agents that } \\
\text { need to pay attention to the pre- } \\
\text { cipitation forecasts and monitor- } \\
\text { ing water height; } \\
\text { - Making restrictions to car park- } \\
\text { ing on the right and left river } \\
\text { banks; } \\
\text { - Launch a warning to the } \\
\text { citizens and maintain them } \\
\text { informed about the possibility of } \\
\text { an increase in the water level; } \\
\text { - Emergency requires an active } \\
\text { intervention of the citizens in the } \\
\text { protection of their own goods. } \\
\text { Citizens need to safeguard the } \\
\text { products existing inside the cel- } \\
\text { lars. }\end{array}$ \\
\hline III & $\begin{array}{c}\text { Begins } \\
\text { when wa- } \\
\text { ter reaches } \\
67.38 \mathrm{~m} \\
\text { a.s.l. } \\
\text { Ends at } \\
68.63 \mathrm{~m} \\
\text { a.s.l. }\end{array}$ & $\begin{array}{l}\text { On the left bank water } \\
\text { completely flooded the } \\
\text { cellars, a street (Av. }^{\text {a }} \\
\text { Beira Rio) and a garden } \\
\text { (Jardim Amadeu de } \\
\text { Sousa Cardozo.) } \\
\text { The water rise by the } \\
\text { sewages and begins to } \\
\text { affect the lower part of } \\
\text { the square called Largo } \\
\text { do Arquinho. } \\
\text { On the right bank the } \\
\text { water height increase } \\
\text { over the flooded infra- } \\
\text { structures. }\end{array}$ & $\begin{array}{l}\text { Damages: The same as the previ- } \\
\text { ous level although the water } \\
\text { height is higher. Probably the } \\
\text { losses of the goods inside the } \\
\text { buildings could increase. } \\
\text { Potential losses and costs: } \\
\text { The level of losses is related with } \\
\text { the preparedness and coping } \\
\text { capacity of the citizens; } \\
\text { Cleaning procedures. }\end{array}$ & $\begin{array}{l}\text { - Launch a warning of "danger- } \\
\text { ous flood"; } \\
\text { - Advice people to protect their } \\
\text { belongings; } \\
\text { - People with shops on the } 31 \\
\text { de Janeiro street and Largo do } \\
\text { Arquinho need to safeguard the } \\
\text { products and equipments; } \\
\text { - Civil protection agents must } \\
\text { maintain citizens informed with } \\
\text { forecasts of water height. They } \\
\text { must be prepared to help the } \\
\text { citizens and to begin evacuation } \\
\text { if the water continues to raise; } \\
\text { - Circumscription of a security } \\
\text { perimeter. }\end{array}$ \\
\hline IV & $\begin{array}{c}\text { Begins } \\
\text { when wa- } \\
\text { ter reaches } \\
68.64 \mathrm{~m} \\
\text { a.s.l. } \\
\text { Ends at } \\
69.27 \mathrm{~m} \\
\text { a.s.l. }\end{array}$ & $\begin{array}{l}\text { The flooding area en- } \\
\text { larges. } \\
\text { On the left river bank the } \\
\text { water reaches up to } 0.50 \\
\mathrm{~cm} \text { on the } 31 \text { de Janeiro } \\
\text { street and inundates the } \\
\text { square called Largo do } \\
\text { Arquinho, } \\
\text { All the commercial area } \\
\text { is flooded. } \\
\text { On the right river bank } \\
\text { the water flooded the } \\
\text { lower part of the car } \\
\text { parking. }\end{array}$ & $\begin{array}{l}\text { Damages: Destruction of } \\
\text { products and restrictions to the } \\
\text { commercial activity on both river } \\
\text { banks. } \\
\text { Potential losses and costs: } \\
\text { Could be important but are re- } \\
\text { lated with the preparedness and } \\
\text { copying capacity of the citizens. } \\
\text { Cleaning procedures. }\end{array}$ & $\begin{array}{l}\text { - The civil protection agents } \\
\text { inform and help affected people; } \\
\text { - People living in inundation } \\
\text { area have to be evacuated; } \\
\text { - People save their goods and } \\
\text { some of them need help from the } \\
\text { authorities to find a place to store } \\
\text { their belongings; } \\
\text { - Maintenance of security } \\
\text { perimeter and restrict the access } \\
\text { and facilitate the evacuation of } \\
\text { people and goods from the area. }\end{array}$ \\
\hline
\end{tabular}


Table 1. Cont.

\begin{tabular}{|c|c|c|c|c|}
\hline $\begin{array}{l}\text { Flood } \\
\text { level }\end{array}$ & $\begin{array}{l}\text { Water } \\
\text { height }\end{array}$ & Exposure & Susceptibility & Coping measures \\
\hline $\mathbf{V}$ & $\begin{array}{c}\text { Begins } \\
\text { when wa- } \\
\text { ter reaches } \\
69.28 \mathrm{~m} \\
\text { a.s.l. } \\
\text { Ends at } \\
71.05 \mathrm{~m} \\
\text { a.s.l. }\end{array}$ & $\begin{array}{l}\text { The river floods the } \\
\text { main commercial area } \\
\text { with more than } 0.50 \mathrm{~m} \\
\text { water height on the } 31 \\
\text { de Janeiro and Largo do } \\
\text { Arquinho. } \\
\text { Most of the ground- } \\
\text { floor of the buildings is } \\
\text { entirely affected. } \\
\text { On the left river bank } \\
\text { the first and second floor } \\
\text { of the market is flooded } \\
\text { including some shops. } \\
\text { The camping located in } \\
\text { this bank is also flooded } \\
\text { as well as the restaurant } \\
\text { inside it. }\end{array}$ & $\begin{array}{l}\text { Damages: Destruction of the } \\
\text { products and equipments inside } \\
\text { stores, coffee shops and restau- } \\
\text { rants. } \\
\text { The buildings can suffer dam- } \\
\text { ages even in the structure. } \\
\text { Potential losses and costs: Can } \\
\text { be very high but will depend of } \\
\text { the preparedness of the citizens } \\
\text { and the capacity to anticipate } \\
\text { and to cope of the civil protec- } \\
\text { tion agents and citizens. } \\
\text { Cleaning measures. }\end{array}$ & $\begin{array}{l}\text { - Evacuation of all local people; } \\
\text { - Monitoring the level of the } \\
\text { water; } \\
\text { - Maintenance of security perim- } \\
\text { eter and restrict the access; } \\
\text { - Preserve the security inside the } \\
\text { area. }\end{array}$ \\
\hline VI & $\begin{array}{c}\text { Begins } \\
\text { when wa- } \\
\text { ter reaches } \\
71.06 \mathrm{~m} \\
\text { a.s.l. }\end{array}$ & $\begin{array}{l}\text { The water height reached } \\
\text { a record level never } \\
\text { known. } \\
\text { The first floor of the } \\
\text { buildings area affected. }\end{array}$ & $\begin{array}{l}\text { Damages: Destruction of the } \\
\text { products and equipments inside } \\
\text { stores, coffee shops, restaurants } \\
\text { and homes. } \\
\text { The buildings can suffer dam- } \\
\text { ages even to the structure. } \\
\text { Potential losses and costs: Can } \\
\text { be very high but will depend of } \\
\text { the preparedness of the citizens } \\
\text { and the capacity to anticipate } \\
\text { and to cope of the civil protec- } \\
\text { tion agents and citizens. }\end{array}$ & $\begin{array}{l}\text { - Maintenance of security perim- } \\
\text { eter and restrict the access; } \\
\text { - Preserve the security in the } \\
\text { area. }\end{array}$ \\
\hline
\end{tabular}

1955 (Table 2, 3) the data available indicated 98 floods in Amarante covering the period of 387 days. Presenting these data in one year frame, on average 22 days of floods were registered. Most of them $(89.8 \%)$ reached only the level I on the proposed scale, and occurred every year. The water height can be variable and reach between

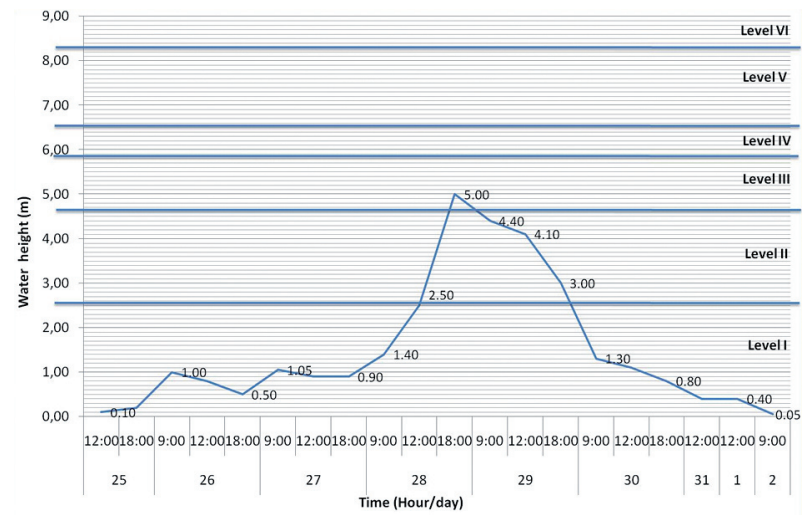

Fig. 5. January 1948 flood.

Source: Data from the National Water Institute (INAG). a few centimeters up to approximately $2.40 \mathrm{~m}$. In fact, most of level I floods $(n=64)$ presented a water height lower than $1 \mathrm{~m}$. The damages were very restricted and were mainly related to the interruption of the utilization of exposed structures which affect leisure. The mean duration of level I floods was 3 days, but may vary from less than a

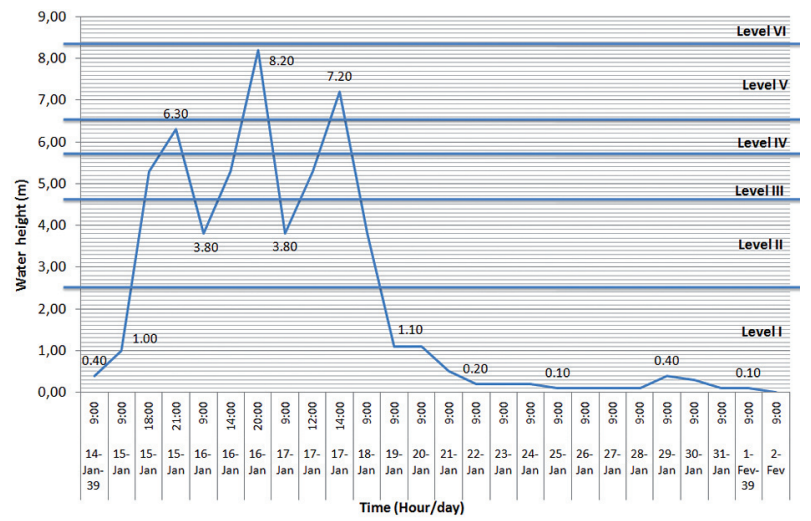

Fig. 6. January 1939 flood. Source: Data from the National Water Institute (INAG). 
Table 2. Flood events between 1937 and 1955

\begin{tabular}{|c|c|c|c|c|c|c|}
\hline $\begin{array}{c}\text { Hydrological } \\
\text { year }\end{array}$ & $\begin{array}{c}\text { Number of } \\
\text { events }\end{array}$ & $\begin{array}{c}\text { Number of } \\
\text { days with } \\
\text { floods }\end{array}$ & $\begin{array}{c}\text { Maximum } \\
\text { altitude } \\
\text { (m a.s.1.) }\end{array}$ & $\begin{array}{c}\text { Number of } \\
\text { flood peak by } \\
\text { event }\end{array}$ & $\begin{array}{c}\text { Maximum } \\
\text { water height } \\
\text { (m) }\end{array}$ & $\begin{array}{c}\text { Maximum } \\
\text { level of flood } \\
\text { classification }\end{array}$ \\
\hline $1937 / 38$ & 3 & 10 & 63.55 & 1 & 0.80 & I \\
\hline $1938 / 39$ & 6 & 27 & 70.95 & 3 & 8.20 & V \\
\hline $1939 / 40$ & 10 & 32 & 66.15 & 4 & 3.40 & II \\
\hline $1940 / 41$ & 7 & 61 & 66.55 & 5 & 3.80 & II \\
\hline $1941 / 42$ & 5 & 7 & 64.55 & 1 & 1.80 & I \\
\hline $1942 / 43$ & 3 & 34 & 64.95 & 3 & 2.20 & I \\
\hline $1943 / 44$ & 3 & 11 & 64.95 & 2 & 2.20 & I \\
\hline $1944 / 45$ & 2 & 3 & 63.05 & 2 & 0.30 & I \\
\hline $1945 / 46$ & 8 & 25 & 65.15 & 5 & 2.40 & I \\
\hline $1946 / 47$ & 7 & 69 & 66.20 & 12 & 3.50 & II \\
\hline $1947 / 48 *$ & 5 & 19 & 67.75 & 3 & 5.00 & III \\
\hline $1948 / 49$ & 4 & 7 & 64.95 & 1 & 2.20 & I \\
\hline $1949 / 50$ & 5 & 10 & 64.80 & 3 & 2.05 & I \\
\hline $1950 / 51$ & 9 & 35 & 66.95 & 6 & 4.20 & II \\
\hline $1951 / 52$ & 7 & 14 & 66.95 & 2 & 4.20 & II \\
\hline $1952 / 53$ & 5 & 12 & 64.35 & 1 & 1.60 & I \\
\hline $1953 / 54$ & 5 & 7 & 63.35 & 1 & 0.60 & I \\
\hline $1954 / 55$ & 4 & 4 & 66.05 & 1 & 3.30 & II \\
\hline Total & 98 & 387 & & & & \\
\hline
\end{tabular}

* There are no records for February and March.

Source: Data from S. Gonçalo staff gorge belonging to the National Water Institute (INAG).

day up to 30 days. Actually, most of these events duration is diminished to 6 days $(88.6 \%)$ The flooding area on these events is not very large (Fig. 2).

During the analyzed period only in 8 years floods on a level II or higher were observed (Table 4), with duration between 1 and 31 days. However, in most cases floods not reached the level II for more than 2 days.

Only one level III flood was registered during this period, beginning on January $25^{\text {th }} 1948$ and lasting until February $2^{\text {nd }}$ of the same year. The flood holded level III for less than a day and level II for less than 2 days. The peak was reached on January $28^{\text {th }}$ (Fig. 5).

The flood that reached level $\mathrm{V}$ happened on the $16^{\text {th }}$ of January 1939. It had the duration of 20 days and begun on January $14^{\text {th }}$ and ended on February $2^{\text {nd }}$ (Fig. 6). Nevertheless, only during three days it reached level II or higher. It is possible to conclude that highest levels of flood have a short duration. During this event it is possible to identify three flood peaks.
Table 3. Flood events in relation to the classification level in each year

\begin{tabular}{|c|c|c|c|c|c|c|}
\hline \multirow{2}{*}{$\begin{array}{c}\text { Hydrological } \\
\text { year }\end{array}$} & Total of flood & \multicolumn{5}{|c|}{ Flood level } \\
\hline & events & I & II & III & IV & V \\
\hline $1937 / 38$ & 3 & 3 & & & & \\
\hline $1938 / 39$ & 6 & 5 & & & & 1 \\
\hline $1939 / 40$ & 10 & 9 & 1 & & & \\
\hline $1940 / 41$ & 7 & 4 & 3 & & & \\
\hline $1941 / 42$ & 5 & 5 & & & & \\
\hline $1942 / 43$ & 3 & 3 & & & & \\
\hline $1943 / 44$ & 3 & 3 & & & & \\
\hline $1944 / 45$ & 2 & 2 & & & & \\
\hline $1945 / 46$ & 8 & 8 & & & & \\
\hline $1946 / 47$ & 7 & 6 & 1 & & & \\
\hline $1947 / 48^{*}$ & 5 & 4 & & 1 & & \\
\hline $1948 / 49$ & 4 & 4 & & & & \\
\hline $1949 / 50$ & 5 & 5 & & & & \\
\hline $1950 / 51$ & 9 & 8 & 1 & & & \\
\hline $1951 / 52$ & 7 & 6 & 1 & & & \\
\hline $1952 / 53$ & 5 & 5 & & & & \\
\hline $1953 / 54$ & 5 & 5 & & & & \\
\hline $1954 / 55$ & 4 & 3 & 1 & & & \\
\hline Total & 98 & 87 & 8 & 1 & 0 & 1 \\
\hline
\end{tabular}

* There are no records for February and March.

Source: Data from S. Gonçalo staff gorge belonging to the National Water Institute (INAG). 
Table 4. Duration of flood events

\begin{tabular}{|c|c|c|c|c|c|c|c|c|c|c|c|}
\hline \multirow{3}{*}{ Flood duration (days) } & \multicolumn{11}{|c|}{ Number of floods by level } \\
\hline & \multirow{2}{*}{$\begin{array}{c}\text { Level I } \\
\text { Number }\end{array}$} & \multirow[b]{2}{*}{$\%$} & \multicolumn{2}{|c|}{ Level II } & \multicolumn{2}{|c|}{ Level III } & \multicolumn{2}{|c|}{ Level IV } & \multicolumn{2}{|c|}{ Level V } & \multirow{2}{*}{ Total } \\
\hline & & & Number & $\%$ & Number & $\%$ & Number & $\%$ & Number & $\%$ & \\
\hline$<=1$ & 42 & 42.86 & 1 & 1.02 & & & & & & & 43 \\
\hline 2 a 5 & 36 & 36.73 & 2 & 2.04 & & & & & & & 38 \\
\hline 6 a 9 & 5 & 5.10 & & & 1 & 1.02 & & & & & 6 \\
\hline 10 a 14 & 3 & 3.06 & 2 & 2.04 & & & & & & & 5 \\
\hline 15 a 19 & 1 & 1.02 & 1 & 1.02 & & & & & & & 2 \\
\hline 20 or more & 1 & 1.02 & 2 & 2.04 & & & & & 1 & 1.02 & 4 \\
\hline Total & 88 & 89.80 & 8 & 8.16 & 1 & 1.02 & & & 1 & 1.02 & 98 \\
\hline
\end{tabular}

Source: Data from the National Water Institute (INAG).

Between 1937 and 1955 the flood season was very large. The earliest occurrence was registered on October $14^{\text {th }} 1939$ and the latest one on June $8^{\text {th }} 1946$. Both reached only level I. Floods with higher magnitude occurred in January and February but two level II floods were also registered in November. The highest flood of this period occurred in January 1939. The occurrence of floods during spring was not an extraordinary situation because 19 events happened in 8 years (1939, 1941, 1942, 1944, 1946, 1947, 1952, 1953 and 1954). They were all of level I.

Concerning the rise of water level, the maximum registered increase was $0.95 \mathrm{mh}^{-1}$, attained during the flood of $16^{\text {th }}$ of January 1939. The drop of the water level was slower and the highest value reached, $0.34 \mathrm{mh}^{-1}$, recorded during the same flood.

\section{Flood occurrence between 1956 and 1984}

During this analyzed period no local hydrometric data were recorded. The only identified flood reached the peak on $1^{\text {st }}$ of April 1962, registered on the wall of some buildings, because it was one of the biggest events that have affected Amarante. It reached level $\mathrm{V}$ but the water height was lower than the one registered during the flood 1939-01-16.

From newspaper reports it was possible to identify 12 floods (Table 5). However, descriptions made by journalists do not always present enough elements to support the classification of these events into levels.

\section{Flood occurrence between 1985 and 2001}

From the data provided by EDP it was possible to identify 11 floods of level II or higher with different duration and water height from October 1985 until March 2001 (Table 6). Some of them present more than one peak (Fig. 7). In the current research the data for the occurrence of level I floods was not available for the reasons explained above.

The 2000/2001 winter was an exceptional period due to the number of floods, their long time duration, and also because of the number of events with a level higher than II. Newspapers and citizens identify the $7^{\text {th }}$ of December and the $5^{\text {th }}$ of January floods as two different events. Nevertheless, they are peaks of the same event (Fig. 8). Considering these two dates as a single event, six episodes were registered. The last one was the biggest of at least the last hundred years.

Table 5. Flood occurrence between 1956 and 1984

\begin{tabular}{|c|c|}
\hline Date of flood peak & Flood level \\
\hline $17^{\text {th }}$ November 1960 & Level IV \\
\hline $1^{\text {st }}$ April 1962 & Level V I \\
\hline $9^{\text {th }}$ January 1963 & Level II \\
\hline $22^{\text {th }}$ January $1966^{1,2}$ & Level III \\
\hline $12^{\text {th }}$ February $1966^{2}$ & $\begin{array}{c}\text { No data } \\
\text { available }\end{array}$ \\
\hline $20^{\text {th }}$ February $1966^{2}$ & $\begin{array}{c}\text { No data } \\
\text { available }\end{array}$ \\
\hline $17^{\text {th }}$ March 1969 & Level III \\
\hline $18^{\text {th }}$ February 1972 & Level III or IV \\
\hline $28^{\text {th }}$ February 1978 & Level IV \\
\hline $7^{\text {th }}$ February 1979 & Level III \\
\hline $30^{\text {th }}$ December 1981 & Level V \\
\hline Between $21^{\text {st }}$ and $27^{\text {th }}$ December $1978^{3}$ & Level III \\
\hline
\end{tabular}

Source: Local newspapers; 1 - Costa (2002); 2 - Newspapers were not available; 3 - Newspapers do not identify the day of the flood peak. 
Table 6. Flood events of level II or higher from 1985 until 2001

\begin{tabular}{|c|c|c|c|}
\hline Date of flood peak & Flood Level & Flood duration & Highest water level (m) \\
\hline $21^{\text {st }}$ December $1989^{1}$ & Level III & 13 days and 18 hours & 4.89 \\
\hline $4^{\text {th }}$ December $1992^{1}$ & Level II & 4 days and 2 hours & 4.18 \\
\hline $6^{\text {th }}$ January $1994^{1}$ & Level II & 12 days and 16 hours & 3.96 \\
\hline $2^{\text {nd }}$ January $1996^{1}$ & Level III & 41 days and 12 hours & 5.12 \\
\hline $6^{\text {th }}$ November $2000^{1}$ & Level II & 2 days and 7 hours & 3.68 \\
\hline $7^{\text {th }}$ December $2000^{1}$ & Level III & \multirow{2}{*}{$\begin{array}{c}\text { At least } 35 \text { days and } 13 \\
\text { hours }\end{array}$} & 4.90 \\
\hline $5^{\text {th }}$ January $2001^{2,6}$ & Level IV & & $5.89^{2}$ (at least) \\
\hline $26^{\text {th }}$ January $2001^{2}$ & Level IV & Not available & $5.89^{2}$ (at least) \\
\hline $7^{\text {th }}$ February $2001^{4}$ & Level II or III & Not available & $2.56^{2}$ \\
\hline $4^{\text {th }}$ March 2001 & Level IV & Not available & $5.89^{3}$ \\
\hline $21^{\text {st }}$ March $2001^{5}$ & Level V & Not available & 8.31 \\
\hline
\end{tabular}

Source: 1 - Data from EDP; 2 - These values are estimated. Due to a failure in the equipment the data was only available until 10 a.m. $5^{\text {th }}$ of January; 3 - This value was estimated from the newspaper descriptions; 4 - It was not found any news about this event in the newspapers. The EDP records are not conclusive about the peak of this event because of a failure in the equipment; 5 - This value is registered on the wall; 6 - Began $30^{\text {th }}$ of November 2000 until, $5^{\text {th }}$ of January 2001 (at least).

This flood season began on the $2^{\text {nd }}$ of November with a level I event with duration of 13 hours. During this month six more floods of level I occurred, some of them with very short duration (e.g. the flood on $13^{\text {th }}$ of November lasted for only 2 hours). On $5^{\text {th }}$ of November the water height began to rise again and reached level II on the following day. The water height increased reaching $3.68 \mathrm{~m}$. The flood duration was 43 hours but only during 3 hours maintained on level II. It is possible to say that since $30^{\text {th }}$ of November 2000 to $5^{\text {th }}$ of January 2001 the water height maintained level I with small and short duration episodes of level II (i.e. $5^{\text {th }}, 10^{\text {th }}, 30^{\text {th }}$ of December and $1^{\text {st }}, 2^{\text {nd }}$ and $4^{\text {th }}$ of January). In this case we can consider that is the same event with two peaks (i.e. $7^{\text {th }}$ of December 2000 and $5^{\text {th }}$ of January 2001). Possibly this situation continued for more days after the $5^{\text {th }}$ of January flood but there are no data available to prove it. The $7^{\text {th }}$ of December flood reached level

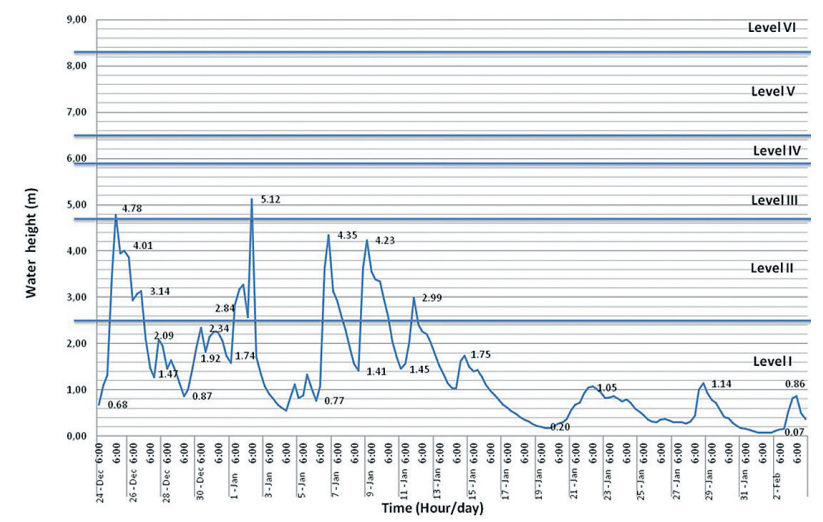

Fig. 7. December 1995 and January 2006 flood. Source: Data from EDP - Energias de Portugal.
III, however higher events occurred after and on the $21^{\text {st }}$ of March happened the highest event recorded in the last hundred years.

Even for floods in the same level the water height may vary, that has different impacts on the exposed elements.

The discharge capacity is an important parameter that can also contribute in the increase of losses. A more rapid rise of the water implies less time for people to cope. There is a great variability of flow velocity and for this period the values found were higher than the ones found in 1937-1955. In December 2000 when the water level rose, the flow velocity was 0.92 and 0.98 $\mathrm{mh}^{-1}$. Moreover, the maximum value of flow velocity calculated when the water level rose was $1.35 \mathrm{mh}^{-1}$ on the $2^{\text {nd }}$ of January 1996 flood. The highest value of discharge capacity, when the water descends, was registered during the $6^{\text {th }}$ of November 2000 flood.

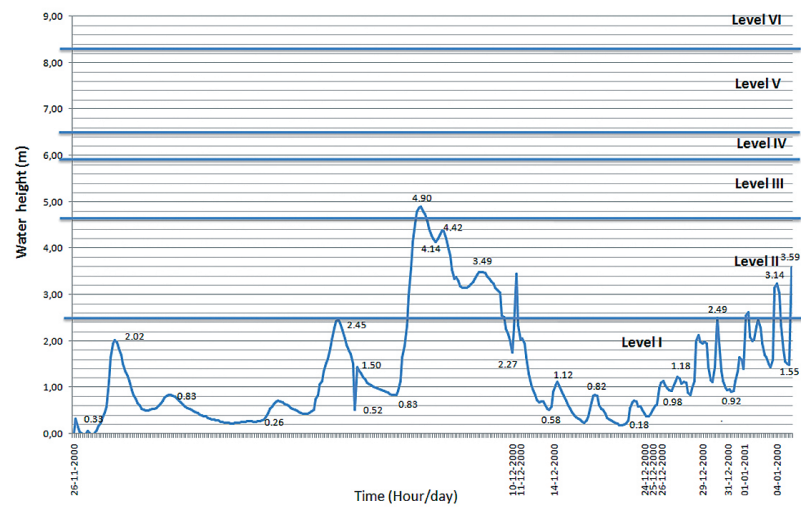

Fig. 8. $26^{\text {th }}$ November 2000 until $5^{\text {th }}$ of January 2001 flood. Source: Data from EDP - Energias de Portugal. 
Also the moment of the day when the flood peak happens can influence the amount of damages. It has impact on the level of surveillance, namely of the citizens and, consequently, on the readiness to cope. In the lower floor most of the buildings are occupied by stores, restaurants and coffee shops. Only on the first or upper floors there are residences. Most of the shops owners do not live in the area which makes the reception and consequently, the response, on the warning difficult. For instance, in the case of the highest floods (i.e. $16^{\text {th }}$ of January 1939 and $21^{\text {st }}$ of March 2001), the flood peak occurred during the night.

Even though a flood always causes disturbances in the people daily lives as well as damages, depending on the season those can be aggravated (e.g. Christmas and Carnival). Many floods affected the area on Christmas and New Year when the shops have more products and there was an increase in commercial activity which could difficult the level of preparedness and increases the damages. The analysis of the flood parameters previously described seems important to support a better emergency planning.

\section{The $21^{\text {st }}$ March 2001 flood management}

During the 2000/2001 winter several stores, coffee shops and restaurants suffered damages as consequence of floods. Nevertheless, the most severe event occurred on $21^{\text {st }}$ March 2001. Although the area inundated was small (21 ha) (Fig. 9) and the number of people affected was reduced (about 100 people ${ }^{1}$ ), the direct losses recorded were established on 1.3 million Euros ${ }^{2}$. This assessment was made by the Associação Comercial de Amarante [Amarante Commercial Association], through a survey prepared for the purpose of requesting financial assistance from the Portuguese government. The effective losses of this event are unknown. In the survey, made in 2001, 67 shops with very different levels of damages were recorded (Fig. 10, Table 7). Damages result from the proximity of the river, but also from other factors like the characteristics of stored goods (e.g. some shops had heavy, fragile

\footnotetext{
This value was calculated using the 2001 Census.

2 Evaluation of the Associação Comercial de Amarante [Amarante Commercial Association]
}

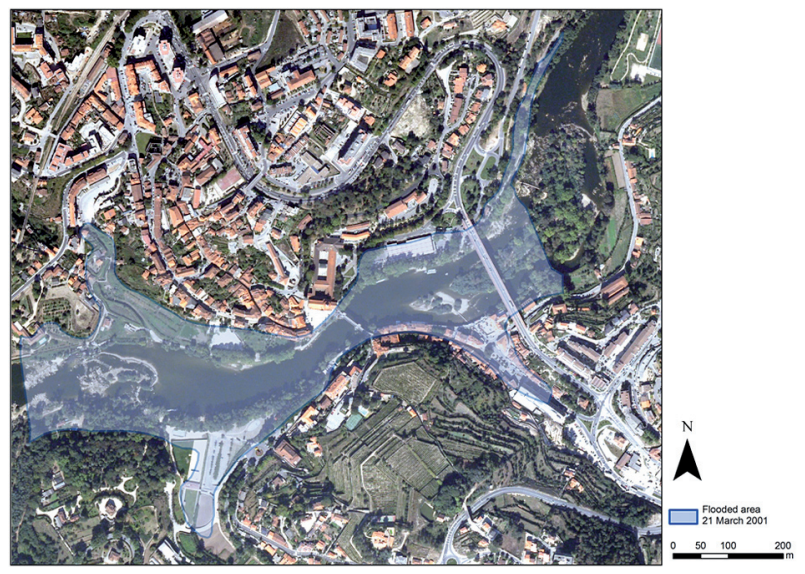

Fig. 9. Area flooded the $21^{\text {st }}$ of March 2001.

Source: Câmara Municipal de Amarante [Amarante City Hall].

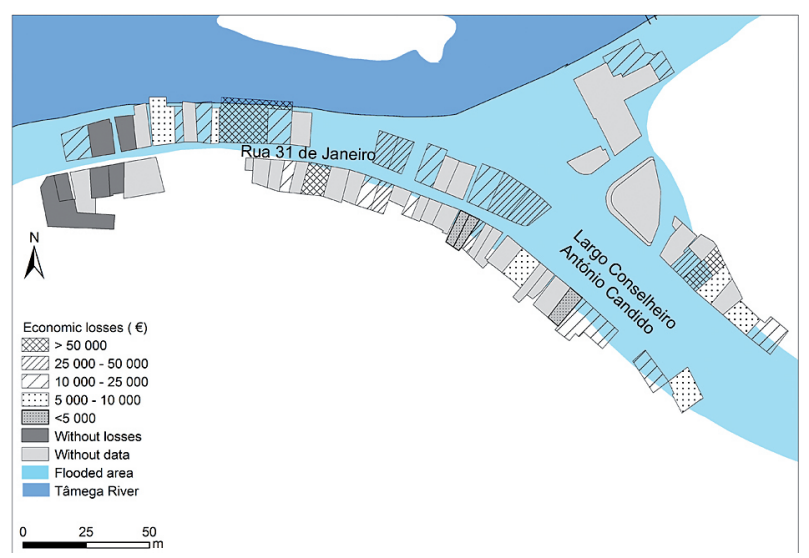

Fig. 10. Losses associated to direct damages during the flood $21^{\text {st }}$ of March.

Source: Amarante Commercial Association (2001).

Table 6. Damages of the flood 21 ${ }^{\text {st }}$ of March 2001

\begin{tabular}{|c|r|r|r|}
\hline \multirow{2}{*}{$\begin{array}{c}\text { Damages } \\
\text { (Euros) }\end{array}$} & \multirow{2}{*}{ No. } & \multicolumn{2}{|c|}{ Total amount } \\
\cline { 3 - 4 } & & \multicolumn{1}{|c|}{ Euros } & \multicolumn{1}{c|}{$\%$} \\
\hline$<2500$ & 6 & 8950 & 0.68 \\
\hline $2501-5000$ & 7 & 27670 & 2.09 \\
\hline $5001-12500$ & 21 & 184475 & 13.96 \\
\hline $12501-25000$ & 16 & 289485 & 21.90 \\
\hline $25001-50000$ & 12 & 406020 & 30.72 \\
\hline$>50000$ & 5 & 405115 & 30.65 \\
\hline Total & 67 & 1321715 & 100.00 \\
\hline
\end{tabular}

Source: Amarante Commercial Association (2001),

equipment, very difficult to move away), and the preventive measures adopted before the flood (e.g. capacity to collect and store the goods and to protect the equipment). The most important, direct and tangible losses are destruction of goods and shop equipments but also interruption of the businesses. 
The questionnaire implemented in 2009 , found six shops owners that did not have the experience of the 2000/2001 floods because they were not yet established in the area. As a response to the questionnaire 18 answers were obtained and for most of them the $21^{\text {st }}$ of March flood was effectively the most important event of that winter, which caused the highest losses, maintained more people and for longer period stayed out of their residence or work place (most of them between 12 hours and 18 hours). However, many of the inquired people recovered in a week or less than a month and only for three people it took several months. Even though, some individuals had a previous long experience of managing floods, this event surprised them. Also the three questionnaire responders working within the study area for more than 20 years did not think that the occurrence of flood with such high water height was possible.

The people are conscientious that there is a high probability to be affected by floods which are not considered as excessively destructive. Even though these events occur sporadically the residents and/or shop owners consider that preparedness is fundamental to decrease the damages and it is not a big disturbance for them to prepare for floods.
People start to think about the floods when the autumn arrives but their attention increases with rainfall intensity. To pay attention to the meteorological forecasts, the civil protection information and alerts broadcasted by radio and television are referred as usual procedures. Despite general awareness and concern, two of the inquired referred only thinking about floods when their occurrence is imminent.

Most of the inquired people feel themselves as sufficiently prepared, nevertheless classified their neighbors' preparedness inferior and even lower the preparedness of the civil protection agents (Table 7). About $58 \%$ of the inquired considered having the sufficient information to prepare for a flood event. It is fundamentally a result of past experiences. The family, friends and the media are also important sources of information. Only four $(22 \%)$ of the inquired referred that they receive each year information about flood possibility and prevention measures from the Municipal Civil Protection Service.

After the experience of the $21^{\text {st }}$ of March flood, less than $50 \%$ of the inquired considered themselves more prepared to face a similar event. On the one hand it is a consequence of a lack of information to support preparedness. On the other hand, even though they have information, there are some limitations that hinder the prepared-

Table 7. Preparedness of citizens to floods

\begin{tabular}{|c|c|c|c|}
\hline \multicolumn{2}{|r|}{ Variable $^{123}$} & \multirow{2}{*}{$\begin{array}{c}\text { Mean } \\
3.25\end{array}$} & \multirow{2}{*}{$\begin{array}{c}\begin{array}{c}\text { Standard } \\
\text { deviation }\end{array} \\
1.13 \\
\end{array}$} \\
\hline \multirow{4}{*}{$\begin{array}{l}\text { Evaluation of pre- } \\
\text { paredness level }^{1}\end{array}$} & Oneself & & \\
\hline & Neighbours & 3.07 & 0.73 \\
\hline & Municipal Civil Protection Service & 2.44 & 1.03 \\
\hline & Fire-fighters & 2.71 & 0.83 \\
\hline \multirow{7}{*}{$\begin{array}{l}\text { Preparation for } \\
\text { floods }^{2}\end{array}$} & Floods are too destructive in order for me to take care about them & 1.62 & 0.77 \\
\hline & The probability that a flood might affect me is low & 2.46 & 1.33 \\
\hline & Prepare myself for the floods is a great inconvenient & 2.46 & 1.27 \\
\hline & $\begin{array}{l}\text { There are no advantages in preparing for the floods as they happen } \\
\text { sporadically }\end{array}$ & 2.50 & 1.16 \\
\hline & It is difficult for me to prepare for the floods & 3.07 & 1.21 \\
\hline & Prepare for the floods reduces significantly the risks & 4.08 & 1.04 \\
\hline & I am conveniently prepared to face floods & 3.38 & 0.87 \\
\hline \multirow{2}{*}{$\begin{array}{l}\text { Preparedness im- } \\
\text { provement }^{3}\end{array}$} & $\begin{array}{l}\text { Develop a joint action with my neighbours in order to prevent the } \\
\text { impacts of a future flood }\end{array}$ & 4.00 & 0.88 \\
\hline & $\begin{array}{l}\text { Participate in some activity to prevent the impacts of a future flood } \\
\text { promoted by Municipal Civil Protection }\end{array}$ & 3.62 & 1.19 \\
\hline
\end{tabular}

Source: Survey, 2009.

${ }^{1}$ The variable were coded in a 5 points scale: (1) Not prepared to (5) Very Prepared; ${ }^{2}$ The variables were coded in a 5 points scale: (1) Disagree totally to (5) Totally Agree; ${ }^{3}$ The variables were coded in a 5 points scale: (1) Never to (5) Always. 
ness and also the capacity to cope (e.g. age, people alone without employers or family close to help, no driving license to easily transport the products, stay out of the area). Needless to say, that when inhabitants in a region are informed about flood coping strategies, they are better prepared for adequate countermeasures (Hansson et al. 2008).

The inquired citizens showed a great availability to develop actions with the neighbours to improve preparedness but they are also available to participate in activities develop by the Municipal Civil Protection Service. Increase the cooperation between civil Protection and the citizens is fundamental to decrease damages.

On the $21^{\text {st }}$ of March 2001 the Municipal Civil Protection Service launched a warning through direct contact and telephone. Within interrogated people only five (28\%) of the inquired lived in the area and as the flood peak occurred during the night many shops owners were not in the area. The main problem was contacting them by mobile phone and some of them only arrived at the place when it was too late to safeguard their belongings. The warning time was very dependent on the quality of the forecast, and the way to warn shops owners that do not live in Amarante, or are not in Amarante on the weekends and holidays, continue to be a big challenge that needs to be improved.

However, even before the Civil Protection flood warning some experienced people recognized the threat posed by the growth of the river and began to take some prevention measures which was fundamental to decrease the losses. On the contrary, other people left the shops without realizing the danger and did not believe that another flood may occur.

Even those who believed in the possibility of a new flood event did not expect that the $21^{\text {st }}$ of March episode would reach such a high level. In fact, many people that had put the goods on an upper level inside the shop did not have time to store them in the uppers floors of buildings or in the case of shops without a storage place to transport it outside the flooded area. At that time the City Hall had new garbage containers that made the traders available to facilitate the storage and also helped shop owners in the transportation of their products from the affected areas. This mea- sure contributed to diminish the losses. A lack of places to store the products was identified.

Although some people had time to safeguard their belongings the damages were high, because not all goods and equipment were easy or even possible to move away. The destruction of the windows and doors was frequent, that explain the option of some shop owners, who fixed the furniture to the walls and kept the doors open. The structural damages were very small. Only one shop wall fell down.

People considered family and friends as the most important help to deal with flood events. However, the Municipal Civil Protection Service, the police and mainly the fire-fighters brigade were also important.

Nevertheless, the level of trust of the inquired citizens in the local institutions is very low, mainly in the case of the Municipal Civil Protection Service and the company responsible for the dam management. The fire-fighters brigade as well as police forces had more trust.

The politicians used flood events to promote themselves and made promises, but $58 \%$ of the inquired answered that they did not accomplish any of them. It is necessary more coherence and responsibility of the politicians to accomplish the promises and to make the decision process more transparent to the people, identifying the rules and methods of decision.

Some of the inquired (15\%) declared that after floods the City Hall did not take any measure to avoid this kind of occurrences. In this case citizens preparedness is fundamental to decrease the damages. Although, some improvements could be done for a more rapid and efficient flood warning. Concerning the Municipal Civil Protection Service the monitoring of water height and the meteorological forecasts are fundamental to establish the appropriate moment to launch the warning as well as the readiness of the response. The collaboration with several institutions (e.g. fire-fighters brigade, police, EDP, National Civil Protection Authority) was evaluated by the City Hall as very good. Nevertheless some improvements are still possible. It is also fundamental to reinforce the contact between the citizens and the Municipal Civil Protection Service as well as the others civil protection agents in order to establish an operational plan to support the emergency 
management. Without a strong engagement of the citizens in all the process, the risk will not decrease. The City Hall has an Emergency Plan approved in 1999 and reviewed in 2007 without any changes concerning flood management. The $21^{\text {st }}$ of March 2001 flood management experience was not included in the plan and used to improve future response. In fact, sometimes in Portugal, the most important thing is to implement a "politically correct" emergency management plan following the framework defined by the law instead of an effective risk and disaster management.

The capacity to recover is connected with personal attributes (e.g. financial resources) but also with the actuation of different institutions. Most of the affected people used their own resources to recover. The financial sector promoted a subsidized credit line, but most of the people did not use it because they did not see any advantages on it.

The support of the insurance companies was evaluated differently which could be related with the established agreements. In fact, if six of the inquired were satisfied, five complained about the help from the insurance companies and most of them classified the insurance company support as very bad. The shop owners established in the area for a long time have insurance agreements but the newly arriving citizens are not able to establish such agreements.

The $21^{\text {st }}$ of March 2001 flood was an extreme event with a magnitude unknown in the area, that increased the vulnerability of the people and mainly the shop owners. The capacity to cope and to recover was determined by several issues, namely by the perception of the danger, the capabilities of each one to take preparedness or emergency procedures, and the coordination of the different entities involved in the flood management.

\section{Conclusions}

The 2000/2001 winter was effectively an exceptional year concerning the amount of rainfall and the occurrence of floods. The historical floods and rainfall data support this conclusion. We did not find any year with so many events of level II or higher as well as with so many following days with at least a level I floods. The $21^{\text {st }}$ of March 2001 daily maximum of precipitation for Amarante $(100.4 \mathrm{~mm})$ is the second highest ever recorded. Between $1^{\text {st }}$ of October 2001 and the end of March 2001 precipitation amount reached $1923.3 \mathrm{~mm}$. This was a value higher by $21 \%$ than the highest previously registered.

The experience of $21^{\text {st }}$ of March 2001 flood reinforces the importance of decreasing the time to implement the warning of flood, so that people can have more time to safeguard their goods. This entails that better information forecasting water discharge and precipitation as well as a better cooperation between several public and private institutions is needed. In addition, an effective early warning implies that flood endangered people would be able to receive and understand it easily.

As people have different perceptions of floods and of the way to deal with these events, a more detailed work on information and its transformation in effective action must be implemented. Only through a better cooperation between $\mathrm{Mu}-$ nicipal Civil Protection Service and local community it will be possible to reduce the damages.

As the highest floods are not annual events and the lessons learned from the $21^{\text {st }}$ of March 2001 flood were not integrated in Municipal Emergency Plan, being so some benefits from this experience will not upgrade a future flood management response. The reason of such a situation is that people learning from this event may not have the same functions in the City Hall or can move away, and consequently the benefits of the experience are lost.

At the same time in the Amarante flood risk prone area after 2001 new shops appeared, meaning that there are more exposed elements. Last year an alert of flood that remained only at level I put into evidence the lack of knowledge of these new inhabitants. A better communication between Municipal Civil Protection Service and the citizens as well as a higher responsibility and engagement of the local community in flood management will contribute to decrease the losses.

The simple model of classification of floods presented in this paper, identify six levels and certainly each one is associated with a probability of occurrence, with different exposed elements 
and potential damages as well as diverse emergency management procedures. It is our intention to apply this approach in other places with different morphology and flood characteristics in order to analyze the interest and applicability of the concept to support flood management and risk reduction.

The information about flood hazard is indispensable to inform the population and stakeholders about the local risk, for planning of flood control measures and for benefit-cost analyses of these measures (Büchele et al. 2006). However, it is not sufficient. The improvement of vulnerability knowledge is fundamental to support the process in which decision-makers choose the best procedures for risk reduction. It is fundamental to focus on developing responses that are effective in facing uncertainty about the likelihood of high level floods occurrence. Responses should be in the form of processes capable of incorporating new knowledge as it emerges (Handmer et al. 1999) as well as incorporate the lessons from the past experiences, effectively learned and not only lived. In fact, learning from the experience can give a great contribution to improve risk reduction and disaster management. However, this is not an instinctively and automatic process. It implies a post-event analysis and evaluation followed by the integration of new procedures, not only in the institutional level (e.g. emergency planning) but also in the citizens' preparedness.

\section{Acknowledgements}

The authors would like to thank the EDP-Energias de Portugal and the National Water Institute, that provided exclusive data. We also like to give thanks to the Amarante City Hall and Mister António Pedro from "Flor do Tâmega" newspaper. We express our gratitude to all the citizens living in the inundation area of Amarante.

\section{References}

Büchele B., Kreibich H., Kron A., Thieken A., Ihringer J., Oberle P., Merz B. \& Nestmann F., 2006. Flood-risk map- ping: contributions towards an enhanced assessment of extreme events and associated risks. Natural Hazards and Earth System Sciences 6: 485-503.

Costa F.S., 2002. As grandes cheias do Rio Tâmega (o caso do período 1960-1986). Apresentação no $6^{\circ}$ Congresso da Água, APRH, Porto, 18/22 Março de 2002.

EU [European Union], 2007. Directive 2007/60/EC of the European Parliament and of the Council of 23 October 2007 on the assessment and management of flood risks. Online 25.07.2010: http:/ / ec.europa.eu/environment/water/flood_risk/ key_docs.htm.

GOMES S.A.L. \& COSTA F.S., 2004. As cheias urbanas em Amarante - o caso da cheia do rio Tâmega em 2001. Actas do $7^{\circ}$ Congresso da Água, Laboratório Nacional de Engenharia Civil, Lisboa, 8 a 12 de Março 2004, Lisboa, 14 pp.

Handmer J.W., Penning-Rowsell E.C. \& Tapsell S., 1999. Flooding in a warmer world: the view from Europe. In: T.E.Downing, A.A.Olsthoorn \& R.S.J.Tol (Eds), Climate, Change and Risk, Routledge, London: 125-161.

Hansson K., Danielson M. \& EKEnBerg L., 2008. A framework for evaluation of flood management strategies. Journal of Environmental Management 86: 465-480.

INAG [O Instituto da Água, I. P.], 2001. Plano da Bacia Hidrográfica do Rio Douro. Análise e diagnóstico - Caracterização Geral da Bacia Hidrográfica. Ministério do Ambiente e Ordenamento do Território, Vol. III.

INAG [O Instituto da Água, I. P.], 2002. National Water Plan. Instituto Nacional da Água, Vol. I and II. Ministério do Ambiente e Ordenamento do Território, Lisboa.

INAG [O Instituto da Água, I. P.], 2010. Atlas da Água: Águas Superficiais. Online 25.07.2010: http:/ / snirh.pt/

JonKman S.N., BočKarjovab M., KoKC M. \& Bernardinid P., 2008. Integrated hydrodynamic and economic modelling of flood damage in the Netherlands. Ecological Economics 66: 77-90.

Kreibich H., Piroth K., Seifert I., Maiwald H., Kunert U., Schwarz J., Merz B. \& Thieken A.H., 2009. Is flow velocity a significant parameter in flood damage modelling? Natural Hazards and Earth System Science 9: 1679-1692.

KRON W., 2002. Keynote lecture: Flood risk = hazard x exposure x vulnerability. In: B.Wu, Z.-Y.Wang, G.Wang, G.G.H.Huang, H.Fang \& J.Huang (eds.), Flood Defence '2002, Science Press, New York.

Merz B. \& Thieken A.H., 2009. Flood risk curves and uncertainty bounds. Natural Hazards 51(3): 437-458.

MoËL H., van Alphen J. \& Aerts J.C.J.H., 2009. Flood maps in Europe - methods, availability and use. Natural Hazards and Earth System Sciences 9: 289-301.

OFDA [Office of U.S. Foreign Disaster Assistance], 1999. BHR/OFDA Annual Report FY 1999. Online 25.07.2010: http://www.usaid.gov/our_work/humanitarian_assistance/disaster_assistance/ publications/annual_reports/pdf/AR1999.pdf.

Pedrosa A.S. \& Costa F.S., 1999. As cheias do Rio Tâmega. O caso da área urbana de Amarante. Territorium, Revista de Geografia Física aplicada ao ordenamento do território e gestão de riscos naturais, Coimbra 6: 249-78.

Tsakiris G., Nalbantis I. \& Pistrika A., 2009. Critical Technical Issues on the EU Flood Directive, European Water 25/26: 39-51. Online 25.07.2010: http://www.ewra.net/ew/ pdf/EW_2009_25-26_04.pdf 